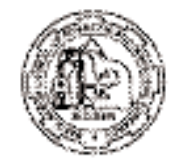

BCSIR
Avaiable online at www.banglajol.info

Bangladesh J. Sci. Ind. Res. 43(3), 301-308, 2008
BANGLADESH JOURNAL OF SCIENTIFIC AND INDUSTRIAL RESEARCH

E-mail: bjsir07gmail.com

\title{
Comparative Study of Different Compost from Different Sources
}

\author{
M. Khalid Iqbal, ${ }^{\text {a Tahira Shfiq, }{ }^{* a} \text { Amana Nadeem }}{ }^{\mathrm{b}}$ and Khurshed Ahmed ${ }^{\mathrm{c}}$ \\ ${ }^{a}$ Center For Environmental Protection Studies PCSIR Lahore, ${ }^{b}$ Govt. College University \\ Faislabad and ${ }^{c}$ NCBA\&E Lahore, Pakistan
}

\begin{abstract}
Municipal solid waste compost is an organic soil additive that can be used in agricultural production, improving soil physical properties, increasing both water retention and supply of essential nutrients. In this study three different types compost were studied. One produce by Lahore City Government second from Patoki compost and third from PCSIR Labs Lahore. These were analyzed for $\mathrm{pH}$, conductivity, organic matter, total nitrogen, $\mathrm{P}_{2} \mathrm{O}_{5}$ and $\mathrm{K}_{2} \mathrm{O}$ by using AOAC method. Average moisture, $\mathrm{pH}$, carbon were highest in Patoki compost while organic matter was lowest (27\%) in Paktoki and highest (56\%) in PCSIR sample. Potassium was maximum in Lahore City Government and Patoki compost, minimum in PCSIR samples. The $\mathrm{C} / \mathrm{N}$ ratio in all compost samples suggest that compost were stable and mature. The concentrations of $\mathrm{Pb}$ and $\mathrm{Zn}$ were also studied.
\end{abstract}

Key words: Compost, Organic matter, Carbon nitrogen ratio, Nutrients.

\section{Introduction}

Effective and safe disposal of municipal solid waste is high on the agenda of developing countries. (Beukerering et al., 1999). Recycling of rapidly emerging, as a preferred strategy in the developed world and the same trend is being cosidered and adopted by developing nations in order to deal with the problems of uncontrolled waste generation and disposal (Cheng et al., 2002, Qureshi 2000, Ludwig et al., 2005).

*Corresponding authour.
The handing of materials for recycling is without environmental impacts, which associated with the utilization of recovered materials in producing new products. The production of new product as compost from agricultural and industrial wastes and municipal by products is an important means of recovering organic matter and an essential method of disposal. Compost is applied to cropland to maintain and improve soil structure and plant nutrients. (Gigliotti et al., 1996). The 
organic waste is decomposed under aerobic conditions with the help of microorganism and results in the compost containing nitrogen, phosphorous, potassium, and at least $20 \%$ of organic matter, which can be successfully substituted for natural fertilizers Municipal solid waste compost (MSWC) as an organic soil additive suggest that it can be used in agricultural production, improving soil physical properties and increasing both water retention and the supply of essential nutrients (McConnell et al., 1993, Rosen et al 1993, Raviv, 1998).

Numerous studies have addressed the use of compost in nursery plant production, and have analyzed its chemical, physical and biological properties (Fitzpatrick, 2001, Sterrett, 2001).

Compost quality has many descriptors such as age, maturity, nutrient content, microbiological, biochemical, heavy metals and pesticide contamination, and chemical and physical properties. However, all these descriptors vary with feedstock sources, the composting technology used, maturity and length of the curing of the compost. (Everett and Phil, 2004)

The study was proposed to analyze the physical, and chemical properties of different compost, whose origins were different. In every compost the organic matter was applied of same nature but the sources of solid waste were not same. The prepared compost of three different sources was collected and compared the quality or concentration of the nutrients was carried out in this study.

\section{Materials and Methods}

Soils are scarce or characterized by low fertility in many parts of the world. Under these circumstances practising traditional organic farming may be difficult. A common solution for conventional growers is the addition of various substrates for soil.

To make up the soil nutrients deficiency and recyling of municipal solid waste, the formation of compost had been started since 2005, by the Lahore City Government with their trade name "ZAMEEN DOST" (compost) under the project of Solid Waste Management. The compost is continued product of city district Government. The second site for sampling was the Tehsil Pattoki compost. The Tehsil Municipal Administration Pattoki had been started, under the Municipal Solid Waste Management project with their trade name "HERYALI" (compost). The third site for sample collection was the PCSIR Labs Lahore. The compost was prepared under controlled conditions and by scientific method to achieve the maximum quality and stability of compost. The compost was prepared by solid waste collected from different locations of the Lahore City.

Compost were selected using random sampling procedure and were collected by hand using vinyl gloves in April-August 2007, carefully packed into polythene bags. Five no of compost samples were collected from each sites, were analyzed and the results were reported in their average ranges. 
Air -dry compost was ground, using a ceramic -coated grinder and used for analysis. The compost samples were weighted on a set of analytical scales with an accuracy of $1 \times 10^{-4}$ g. All the assays employed distilled water and analytical pure reagents.

Method used for the analysis of chemical and nurients characteristics were as fellows: $\mathrm{pH}$ was determine on wet material using a JENCO 6173 (USA), (Chapman and Pratt, 1961), and salinity was measured from the electrical conductivity of a saturated paste extract (Bower and Wilcox, 1965). Nitrogen content was measured on dry matter using the Kjeldhal method (Black et al., 1979); organic matter using the chemical oxygen demand method (Ciavatta et al; 1990); phosphorous by colorimetric spectrophotometry, potassium and metal content was determine by flame photometry and by an atomic absorption spectrometer (AAS).

\section{Digestion on samples for metal estimation}

Nitric-perchloric acid digestion was performed, following the procedure recommended by AOAC (1990). One-gram sample was placed in $250 \mathrm{ml}$ digestion flask and 10 $\mathrm{ml}$ of con $\mathrm{HNO}_{3}$ was added. The mixture was boiled gently for 30-45minutes to oxidize all oxidisable matter. After cooling, $5 \mathrm{ml}$ of $70 \%$ perchloric acid added and was boiled gently until dense white fumes appeared. After cooling $20 \mathrm{ml}$ of distilled water was added and the mixture was boiled further to release any fumes. The solution was cooled, filter through What man No.42 filter paper and $<0.45 \mathrm{um}$ Millipore filtered paper and transferred quantitatively to $25 \mathrm{ml}$ volumetric flask by adding double distilled water. The concentrations of metals $(\mathrm{Zn}, \mathrm{Pb})$ in the solution were determined by an atomic absorption spectrometer (AAS). The data thus obtained was analysis by one way analysis of variance. (Montgomery, 1997)

All reagents were of analytical reagent grade (Merck, Germany). Deionized and double distilled water was used for perparing solutions and making dilutions. Standard solutions prepared for all the studied elements were stored in polyethylene containers.

\section{Results and Discussion}

A number of different criteria have been established to describe the quality of the end product, compost. According to Haug (1993), these inlcude physical, chemical and sensory properties of compost materials such as particle size, colour, moisture, volatile solids, $\mathrm{P}_{2} \mathrm{O}_{5}$ and other nutrients.

The concentration of moisture varied with reference to source of waste, because each source has different water contents. The Patoki compost had maximum moisture while PCSIR sample had low concentration of moisture in their samples. The moisture content of Lahore compost varied from 33.347.00\%. It was recommended by Diaz et al (2003) that the concentration of moisture content of finished compost be less than 30\% 
to achieve separation of larger particles during screening. On the other hand, the recommended moisture contents for compost screening is between 35-45\%. (Dougherty 1999). The PCSIR compost sample was supported by Rynk (2003). Who suggested that this parameter should be less than $40 \%$ to prevent clogging. However Analysis of variance shows that there is no significant difference between the moisture levels of three types of composts as in Table I.I. In all samples the minimum water contents ranged from $30-35 \%$.

Value for $\mathrm{pH}$ ranged from 5.4 to 8.5 , PCSIR $\mathrm{pH}$ compost being the lowest and Potoki sample had highest. Compost $\mathrm{pH}$ values were in all cases over 8. According to Dougherty
(1999) the end product $\mathrm{pH}$ can ranged from 5.5 to 8.0. But p- value as in Table I.II shows that there is no significant difference between the $\mathrm{pH}$ values of all composts samples. Soluble salts contents are measured by electrical conductivity and reported in units of $(\mathrm{ds} / \mathrm{m})$. A significant difference was found between the conductivity of all three types of compost as in Tabe I.III. The salt concentration in all samples was between 5.3 to 19.8 $\mathrm{ds} / \mathrm{m}$. The highest concentration was found in Lahore Compost and lowest in Patoki compost, the PCSIR sample varied from 5.7-17.7 ds/m. which was supported by Dougherty (1999), soluble salt in finished compost may ranged from $1-30 \mathrm{ds} / \mathrm{m}$. All the samples had less than 30 electrical conductivity, which is shown in Table I.

Table I. Comparison of characteristics of different composts

\begin{tabular}{l|l|l|l}
\hline Parameters & Patoki compost & Lahore compost & PCSIR Labs compost \\
\hline Moisture (\%) & $35-50$ & $33.30-47.00$ & $30-40$ \\
$\mathrm{pH}$ & $6.3-8.5$ & $6.48-08.01$ & $5.4-8.2$ \\
Conductivity (dSm-1 & $5.3-18.1$ & $6.90-19.80$ & $5.7-17.7$ \\
Nitrogen (total) (\%) & $1.2-3.5$ & $1.45-04.00$ & $0.7-3.1$ \\
$\mathrm{P}_{2} \mathrm{O}_{5} \mathrm{mg} / \mathrm{kg}$ & $30.9-38$ & $35.3-43.00$ & $31-49$ \\
$\mathrm{~K}_{2} \mathrm{O}$ mg/kg & $145-215$ & $133-224$ & $175-207$ \\
Organic matter (\%) & $39-53.8$ & $27-49$ & $33-56$ \\
$\mathrm{C} / \mathrm{N}$ & $13.7-26.1$ & $16.3-25.5$ & $12.5-19$ \\
\hline
\end{tabular}

Table I.I Analysis of variance of moisture in the three types of composts $(n=5)$

\begin{tabular}{c|c|c|c|c|c|c}
\hline SOV & SS & df & MS & F value & P value & Decision \\
\hline Between & 139.692 & 2 & 69.846 & 2.39 & 0.1334505 & Accept Ho \\
Within & 350.212 & 12 & 29.18433 & & & \\
Total & 489.904 & 14 & & & & \\
\hline
\end{tabular}


Table I.II: Analysis of variance of $\mathbf{p H}$ in three types of composts $(\mathrm{n}=5)$

\begin{tabular}{l|c|c|c|c|c|c}
\hline SOV & SS & df & MS & F value & P value & Decision \\
\hline Between & 0.349813 & 2 & 0.174907 & 0.21 & 0.8130274 & Accept Ho \\
Within & 9.96608 & 12 & 0.830507 & & & \\
Total & 10.31589 & 14 & & & & \\
\hline
\end{tabular}

Table I.III: Analysis of variance of conductivity in three types of composts $(n=5)$

\begin{tabular}{l|c|c|c|c|c|c}
\hline SOV & SS & df & MS & F value & P value & Decision \\
\hline Between & 267.7053 & 2 & 133.8527 & 4.32 & 0.0386192 & Reject Ho \\
Within & 371.804 & 12 & 30.98367 & & & \\
Total & 639.5093 & 14 & & & & \\
\hline
\end{tabular}

The significant difference was observed between the nitrogen contents of all three types of composts as p- value shown in Tabe I.IV. The concentration of nitrogen were ranged from 0.7 to $4.0 \%$. Nitrogen concentration was maximum in Lahore compost and lowest in PCSIR compost. Every sample concentration depends upon the source of solid waste, the composition of solid waste changed with time and location, because all the waste collected from different sources have no segregation. Due to this reason the waste quality contain the different concentration of all nutrients.

In the present study the concentration of $\mathrm{P}$ and $\mathrm{K}$ also varied from each source. In Table
I.V and I.VI by analysis of variance a significant difference was also observed between potassium and phosphate level in all three types of compost composition. The concentration of $\mathrm{K}$ in Lahore compost was 224 $\mathrm{mg} / \mathrm{kg}$ and lowest Patoki sample, while the PCSIR sample was in the ranged of 175-207 $\mathrm{mg} / \mathrm{kg}$. The nutrients values were also increased by the addition of manure, which raised the decomposition rate of waste and also enhance the concentration of phosphorous, nitrogen, and potassium. (Fonstad et al. 2003).

The organic matter concentration in all types of composts was different. A significant different was also observed between these

Table I.IV: Analysis of variance of nitrogen in three types of composts $(n=5)$

\begin{tabular}{l|c|c|c|c|c|c}
\hline SOV & SS & df & MS & F value & P value & Decision \\
\hline Between & 13.10212 & 2 & 6.55106 & 50.91 & 0.0163597 & Accept Ho \\
Within & 9.96608 & 12 & 0.430507 & & & \\
Total & 26.40724 & 14 & & & & \\
\hline
\end{tabular}


Table I.V: Comparison of $\mathrm{P}_{2} \mathrm{O}_{5}$ in three types of composts $(n=5)$

\begin{tabular}{l|c|c|c|c|c|c}
\hline SOV & SS & df & MS & F value & P value & Decision \\
\hline Between & 221.668 & 2 & 110.834 & 3.88 & 0.050104 & Accept Ho \\
Within & 342.668 & 12 & 28.55567 & & & \\
\hline Total & 564.336 & 14 & & & & \\
\hline
\end{tabular}

Table I.VI: Analysis of variance of $K_{2}$ in the three types of composts $(n=5)$

\begin{tabular}{l|c|c|c|c|c|c}
\hline SOV & SS & df & MS & F value & P value & Decision \\
\hline Between & 5803.2 & 2 & 2901.6 & 3.24 & 0.0752107 & Accept Ho \\
Within & 10763.2 & 12 & 896.9333 & & & \\
\hline Total & 16566.4 & 14 & & & & \\
\hline
\end{tabular}

values as shown in Table I.VII. Organic matter content was highest $56 \%$ in PCSIR sample, and lowest $27 \%$ in Lahore compost. As the composition of sample changed, the concentration of organic matter also changed. But the organic matter reported by other scientist was 35 to $70 \%$ must lies in the finished product (Sander et al 2005). All the studied samples organic matter lies between the limits as described by Sander et al(2005).
The $\mathrm{C} / \mathrm{N}$ ratio is widely used as an indicator of the maturity and stability of organic matter. The lowest values recorded here for the $\mathrm{C} / \mathrm{N}$ ratio in MSW compost in all study samples suggest that compost were stable and mature. Davidson et al (1994) reported that compost with a $\mathrm{C} / \mathrm{N}$ ratio of less than 20 is ideal fore plant production. Ratios above 30 may be toxic causing plant death. (Zuccnio et al., 1981). The $\mathrm{C} / \mathrm{N}$ in all samples was

Table I.VII: Analysis of variance of organic matter in three types of composts $(n=5)$

\begin{tabular}{l|c|c|c|c|c|c}
\hline SOV & SS & df & MS & F value & P value & Decision \\
\hline Between & 931.836 & 2 & 465.918 & 6.15 & 0.0144754 & Reject Ho \\
Within & 908.544 & 12 & 75.712 & & & \\
Total & 1840.38 & 14 & & & & \\
\hline
\end{tabular}

Table I.VIII: Analysis of variance of $\mathrm{C} / \mathrm{N}$ in three types of composts $(n=5)$

\begin{tabular}{l|c|c|c|c|c|c}
\hline SOV & SS & df & MS & F Value & P Value & Decision \\
\hline Between & 142.0213 & 2 & 71.01067 & 4.02 & 0.0462173 & Reject Ho \\
Within & 212.196 & 12 & 17.683 & & & \\
Total & 354.2173 & 14 & & & & \\
\hline
\end{tabular}


Table II. Metal contents in MSW compost and prodused limit for different regulations

\begin{tabular}{l|c|c|c|c|c}
\hline Meltal & $\begin{array}{c}\text { Patoki } \\
\text { compost }\end{array}$ & $\begin{array}{c}\text { Lahore } \\
\text { compost }\end{array}$ & $\begin{array}{c}\text { PCSIR Labs } \\
\text { compost }\end{array}$ & Spanish law & Ecolabel \\
\hline $\mathrm{Zn} \mathrm{mg/kg}$ & $451-509$ & $420-488$ & $478-525$ & 1100 & 300 \\
$\mathrm{~Pb} \mathrm{mg/kg}$ & $21-39$ & $65-103$ & $27.7-33$ & 300 & 140 \\
\hline
\end{tabular}

ranged from 13.7-26.1 in Patoki, 16.3-25.5 in Lahore compost and in PCSIR samples were 12.5-19 which is shown in Table I. From these results it was concluded that all $\mathrm{C} / \mathrm{N}$ ratio in all three types of composts were significantly different. No such sample was detected in study, whose $\mathrm{C} / \mathrm{N}$ ratio was over 30.as in Table I.VIII.

MSW compost heavy metals contents as in Table II was in all cases below the maximum levels permitted by Spanish regulation. However, values mostly exceeded the maximum limits established for compost for use with organic products. (Ecolabel 2001/688 /CE).

\section{References}

Association of Analytical Chemist (AOAC), (1990) Official and Tentative Methods of Analysis 12th ed.

Beukerering, P.V. Sekher, M. Gerlagh, R. Kumar, V. (1999). Analyzing Urban solid waste in Developing Countries : a perspective on Bangalore, India working paper no24, Collaborative Research in Economics of Environment and Development (CREED), London,

Black, C.A. Evans, D.D. Ensminger, L.E. White, J.L. Clark, F.E. Dianuer, R.C. (1979).
Methods of Soil Analysis, fifty ed. American Society of Agronomy, Inc. publisher. P.596.

Bower, C.A. Wilcox, L.V. (1965). Methods of Soil Analysis, part 2. American Society of Agronomy. pp. 937-940.

Chapman, H.D. Pratt, P.F. (1961) Methods of analysis for soil plants and water. University of California, Division of Agricultural Sciences pp. 233-234.

Cheng, S. Chan, C.W. Huang, G.H. (2002) Using multiple criteria decision analysis for supporting decision of solid waste management Journal of Environmental Science and Health A 37: 975-990.

Ciavatta, C.V. Antisari, L. Sequi, P. (1990) An enzymatic approach to determination of the degree of stabilization of organic carbon in fertilizers. Fertilizer Research 25: 167-174.

Davidson, H. Mecklenburg, R. Peterson, C. (1994). Nursery management, Administration and Culture, 3rd ed. Prentice Hall, Englewood Cliffs, NJ.

Diaz, L.E. Savage, G.M. Eggerth, L.L. Golueke, C.G. (1993) Composting and Recycling Municipal Solid waste. Lewis Publisher, CRC. Press Inc. pp: 160-162. 
Dougherty, M. (1999). Site consideration, environmental management and safety. Natural resource, Agriculture and Engineering service. pp 70-71.

Ecolabel 2001/ 688/CE. Europinm Commission 2001/ 688/ EC. Establishing ecological criteria for the award of the community eco-label to soil improvers and growing media (notified under document number C (2001) 2597.

Everett, E. Phil, R.W. (2004). Biological assay for compost Quality. Compost Science and Utilization 12: 342-348.

Fitzatrick, G.C. (2001). Compost utilization in ornamental and nursery crop production system. In Stoffella, P.J. Khan .B.A. (Eds), Compost utilization in Horticultural cropping systems. Lewis Publication, Boca Raton, Fl: 135-150.

Fonstad, T.A. Meier, D.E. Ingram, L.J. Leonard J. (2003). Evaluation and demonstration of composting as an option fore dead animal management in Saskatchewan. Canadian Biosystem Engineering. 45: 19-25.

Gigliotti, G. Businelli, D. Giusquiani, P.L. (1996). Trace metals uptake and distribution in corn plants grown on a 6-year urban waste compost amended soil. Agri. Ecosystem. Environ. 58: 199-206.

Haug, T.T. (1993). Compost systems. The practical Handbook of compost Engineering. Lewis Publishers, RC Press Inc pp: 21-93.

Ludwig, C. Hellweg, S. Stucki, S. (2005). Municipal solid waste management, strategies and technologies for sustainable solution, Waste management and Research.
McConnell, D.B. Shiralipour, A. Smith, W. (1993). Compost application improves soil properties. Biocycle 34: 61-63.

Montgomery D.C. (1997). Design and Analysis of experiments. Arizon State University. John Wieley and Sons, New York, USA.

Qureshi, A.P. (2000). Waste Buster: an experience of Pakistan. In: Sinha et.al, (Ed) Community based solid waste management: The Asian Experience, Waste Concern, Dhaka, Bangladesh.

Raviv, M. (1998). Horticultural uses of composted material. Acta, Horticulture 469: 225-234.

Rosen, C. Halbach, T. Swanson, B. (1993). Horticultural uses of municipal solid waste compost. Hortechnology 3: 167-173.

Rynk, R. (2003) Large animal mortality composting goes mainstream. Biocycle 44: 44- 49.

Sander, J.E. Warrington, M.C. Myers, L.M. (2005). Selected methods of animal carcass disposal. Journal of the American veterinary medical Association. 7: 1003-1005.

Spanish regulation. Ordinance on Fertilizers and related Products, 28 May 1998.

Sterrett, S.B. (2001) Compost as horticultural substrates for vegetable transplant production. In Stoffella, P.J. Khan. B.A. (Eds), Compost Utilization in Horticultural Cropping systems. Lewis Publication, Boca Raton, Fl: 227-240.

Zucconi, F. Pera, A. Forte, M. De Bertolli, M. (1981). Evaluating toxicity of immature compost. Biocycle 22: 44-46.

Received : January, 13, 2008;

Accepted : March, 17, 2008. 